\title{
Hypercalcemia in the Emergency Department: Prevalence, Etiology, and Mortality Rate
}

\author{
Acil Serviste Hiperkalsemi; Prevelans, Etiyoloji ve Mortalite Oranı
}

\author{
Semih Korkut ${ }^{1} \oplus$, Ozlem Polat $^{2} \oplus$, Mehmet Hanifi Kazanci ${ }^{3} \oplus$, Halil Dogan $^{1} \oplus$, Deniz Tural ${ }^{4} \oplus$ \\ ${ }^{1}$ Department of Emergency Medicine, University of Health Sciences Bakirkoy Dr. Sadi Konuk Training and Research Hospital, Istanbul, Turkey \\ ${ }^{2}$ Department of Family Medicine, University of Health Sciences Bakirkoy Dr. Sadi Konuk Training and Research Hospital, Istanbul, Turkey \\ ${ }^{3}$ Department of Internal Medicine, University of Health Sciences Bakirkoy Dr. Sadi Konuk Training and Research Hospital, Istanbul, Turkey \\ ${ }^{4}$ Department of Medical Oncology, University of Health Sciences Bakirkoy Dr. Sadi Konuk Training and Research Hospital, Istanbul, Turkey
}

Received: 08 February 2020 / Accepted: 16 May 2020 / Publication date: 26 June 2020

Cite as: Korkut S, Polat Ö, Kazancı MH, Doğan H, Tural D. Hypercalcemia in the emergency department: prevalence, etiology, and mortality rate. Med J Bakirkoy 2020;16(2):143-7.

ABSTRACT

Objective: The aim of the study was to describe the prevalence, clinical characteristics of hypercalcemia and the impacts on renal function and survival in emergency department (ED) patients.

Method: We conducted a retrospective cross sectional descriptive study, all patient admitted between January 1, 2017, and January 1, 2018 to the ED of University of Health Sciences Bakirkoy TAR, were screened for the presence of hypercalcemia, defined as a serum calcium level greater than $10.3 \mathrm{mg} / \mathrm{dL}$. Demographic, laboratory and outcome data were collected.

Results: During the study period, 1.246 of 318.527 patients (120.418 patients received a measurement of serum calcium) (0.01\%) were found to have hypercalcemia (Serum calcium $11.0 \pm 0.8 \mathrm{mg} / \mathrm{dL}$ ) Mild hypercalcemia seen more frequently (calcium level $<12 \mathrm{mg} / \mathrm{dL}$, $94.3 \%$ ). Renal fuction was normal in 995 (79.8\%) of all patients with hypercalcemia. The total mortality rate was $0.01 \%$, and death was associated with higher age, higher calcium level, lower albumin, lower hemoglobin, higher creatinine and higher white blood cells (all $p<0.05)$.

Conclusions: Although hypercalcemia is common in ED, severe hypercalcemia is rare and fatal. Therefore we recommend measuring the serum calcium level in at-risk patients in the ED and treatment should be initiated to detected underlying disease.

Keywords: hypecalcemia, electrolyte disturbance, emergency department

öz

Amaç: Bu çalışmayla acil servise başvuran hastalarda hiperkalsemi prevelansını, klinik özelliklerini, böbrek fonksiyonu üzerine etkilerini ve mortalite oranını belirlemeyi amaçladık.

Yöntem: Retrospektif kesitsel tanımlayıcı olarak 1 Ocak 2017 ve 1 Ocak 2018 tarihleri arasında Sağlık Bilimleri Üniversitesi Bakırköy Dr. Sadi Konuk Eğitim ve Araştırma Hastanesi Acil Servisine başvuran hastalarda, kalsiyum seviyesi 10,3 mg/dL'den daha yüksek olanlar belirlendi. Bu hastaların demografik, laboratuvar ve klinik verileri toplandı.

Bulgular: Bir yıllık süreçte başvuran 318.527 hasta içinden 120.418 hastada kalsiyum seviyesi tetkik edildi ve hastaların 1.246'sında (\%0,01) hiperkalsemi saptandı. (Serum kalsiyum 11,0 $00,8 \mathrm{mg} / \mathrm{dL}$ ). Hastaların \%94,3'ünde hafif hiperkalsemi vardı (kalsiyum seviyesi $<12 \mathrm{mg} / \mathrm{dL}$, $\% 94,3)$. Hastaların \%79,8'inde renal fonksiyonları normaldi. Mortalite oranı \%0,01 idi. ileri yaş, ağır hiperkalsemi, kreatinin yüksekliği ve lökositoz durumları mortalite ile ilişkili saptandı $(p<0,05)$. Ek olarak albumin ve hemoglobin değerleri daha düşük olan hastalarda mortalite oranının arttığı görüldü $(p<0,05)$.

Sonuç: Şiddetli hiperkalsemi nadir görülmesine rağmen ölümcül olabilmektedir. Bu nedenle acil servise başvuran risk altındaki hastalarda serum kalsiyum düzeyini ölçmeyi ve zaman kaybetmeden altta yatan hastalığı tedavi etmeyi öneriyoruz.

Anahtar kelimeler: hiperkalsemi, elektrolit bozuklukları, acil servis

Corresponding Author:

m.kazanci@saglik.gov.tr
S. Korkut 0000-0002-5409-3586

O. Polat $0000-0002-7512-1283$

M.H. Kazanci 0000-0001-9129-6393
H. Dogan 0000-0003-4751-030X

D. Tural 0000-0003-2144-6469

(c) Telif hakkı Sağlık Bilimleri Üniversitesi Bakırköy Dr. Sadi Konuk Eğitim ve Araştırma Hastanesi'ne aittir. Logos Tıp Yayıncılık tarafindan yayınlanmaktadır. Bu dergide yayınlanan bütün makaleler Creative Commons Atff-GayriTicari 4.0 Uluslararası Lisansı ile lisanslanmıştr.

(C) Copyright Health Sciences University Bakırköy Sadi Konuk Training and Research Hospital. This journal published by Logos Medical Publishing.

Licenced by Creative Commons Attribution-NonCommercial 4.0 International (CC BY-NC 4.0) 


\section{INTRODUCTION}

Electrolyte disorders are commonly observed in the ED. Deterioration of calcium levels is very important issue. The clinical range of hypocalcemia and hypercalcemia is wide and can cause death. Although many patients are diagnosed as asymptomatic in practice, it is common in patients applying for ED with different symptoms. There was a few studies on electrolyte disorders in ED. Two of them retrospective study on the epidemiology of hypercalcemia in the ED has been published ${ }^{(1,2)}$. Also a study on hospitalized patients from Hong Kong confirmed hypercalcemia. (Incidence 1\%) ${ }^{(3)}$. A $<5 \%$ incidence was found in hospital admission patients and less than $1.0 \%$ in outpatients ${ }^{(4,5)}$. The clinical range of hypercalcemia is wide. It also cause neurologic symptoms such as weakness, lethargy, and even coma. On the other hand, it causes gastrointestinal signs such as vomiting, nausea ${ }^{(6)}$.

Most patients with hypercalcemia are asymptomatic; but symtoms of hypercalcemia usually proportional to calcium elevation. Symptoms may be rapid onset because of calcium serum level variability and the underlying disease. When serum calcium level exceeds $14.0 \mathrm{mg} / \mathrm{dL}$, hypercalcemia crisis occurs. This is associated with mortality. In this case severe complications may occur. Therefore, it is necessary to measure the serum calcium level in patients admitted to ED. In addition, Hypercalcemia can be seen in conjunction with other electrolyte should be noted. Especially magnesium and sodium homeostasis should be looked at when evaluating patients ${ }^{(7)}$.

We evaluated patients who admitted to the ED with symptoms of hypercalcemia. We investigate the prevalence of hypercalcemia, survival of ED patients and hypercalcemia association with renal failure.

\section{MATERIAL AND METHODS}

In this retrospective descriptive study, the database of the central laboratory of University of Health Sciences Bakirkoy TAR was scanned for elevated serum calcium levels from the Department of ED. All patients admitted between January 1, 2017, and January 1,2018 . In our hospital, the level of serum calcium is 8.6 to $10.3 \mathrm{mg} / \mathrm{dL}$ is normal range. We defined hypercalcemia was serum total calcium concentration greater than $10.3 \mathrm{mg} / \mathrm{dL}$. In addition; serum albumin level affects serum calcium level. Therefore, we perform a correction formula was used to calculate exact calcium level: [1] Corrected total serum calcium level $(\mathrm{mg} / \mathrm{dL})=$ measured total calcium level $(\mathrm{mg} / \mathrm{dL})+0.8 \times[4.0$ - albumin concentration $(\mathrm{g} / \mathrm{dL})]$.

Patients were divided into three parts depending on serum calcium levels. Mild hypercalcemia (10.3-11.9 $\mathrm{mg} / \mathrm{dL}$ ), moderate hypercalcemia (12.0-14.0 mg/dL), and severe hypercalcemia $(>14.0 \mathrm{mg} / \mathrm{dL}$ ). Demographic data (all identified patientes, namely, age and gender) were recorded. Biochemical data including sodium, magnesium, creatine, albumin concentration, renal function test results and hemogram results were also recorded. All patients followed from the duration of in-hospital to until his or her discharge and in-hospital mortality.

Statistical analysis was performed by use of SPSS 19.0. Data are presented as mean \pm SD. Student's t-test, Mann Whitney $U$ test was used to compare demographic and biochemical data between survivor and nonsurvivor groups. $X^{2}$ test used for the statistical significance of the effect of various degrees of hypercalcemia on mortality rate, renal failure, and other variables. In additon, independent variables was selected on factors that showed significant changes between survivors and nonsurvivors. A Pvalue less than 0.05 was statistically significant.

\section{RESULTS}

During in this study, 318527 patients (all admitted patients) were admitted to our ED, of which 120418 (37\%) received a measurement of serum calcium levels. Among them, 1246 patients (0.01\%) presented with hypercalcemia. 635 (51\%) patients were female and 611 (49\%) patients were male. Median serum calcium was $10.77 \mathrm{mg} / \mathrm{dL}$, with $21 \mathrm{mg} / \mathrm{dL}$ being the highest serum calcium value observed. Reference calcium level was $8.6-10.3 \mathrm{mg} / \mathrm{dL}$. Mild hypercalcemia was defined as serum calcium level 10.3-11.9 mg/dL, moderate hypercalcemia was defined as $12-14 \mathrm{mg} / \mathrm{dL}$ and severe hypercalcemia was defined as $14 \mathrm{mg} / \mathrm{dL}$. Most of patients had mild hypercalcemia (calcium level 10.3-12 mg/dL, 94.37\%) 
The level of hypercalcemia in respect to the age distribution of the patients participated in our study which was split into 7 groups (20 years, 20-29 years, 30-39 years, $40-49$ years, $50-59$ years, $60-69$ years, 70 years) is investigated. Mild hypercalcemia found to be significantly $(p=0.003)$ in $20-29$ years $(17.14 \%)$ and $50-59$ years (17.32\%) among all the other age groups. Moderate hypercalcemia found to be significantly $(p=0.000)$ in $50-59$ years $(25.0 \%), 60-69$ years (25.0\%) and 70 years (38.46\%). There was no significant difference in the age distribution of groups with severe hypercalcemia $(p=0.198)$ (Table 2).

In order to track seasonal variation of serum calcium levels, the serum calcium levels of the study samples in respect to each month were investigated. Mild hypercalcemia, the case numbers were significantly $(p=0.000)$ elevated in September $(24.02 \%)$ and

Table 1. Characteristics of Hypercalcemic Patients.

\begin{tabular}{ll}
\hline Female gender, n (\%) & $635(50.96)$ \\
Male gender, n (\%) & $611(49.04)$ \\
\hline
\end{tabular}

October (23.66\%). Moderate/severe hypercalcemia wasn't found to be significantly in respect to each months. Overall, the cases of mild hypercalcemia found to be significantly ( $p=0.0001$ ) elevated among all the other hypercalcemia groups screened during the whole year.

The major determinants of renal failure are serum urea and creatinine values in respect to plasma calcium levels were investigated. As compared to mild hypercalcemia, serum creatinine levels were significantly $(p=0.000)$ elevated in severe hypercalcemia. With increasing calcium level, the incidence of concurrent renal failure also increased after the uremic group is excluded. Also, urea levels found to be decreased in mild hypercalcemia as compared to severe hypercalcemia.

Since anemia is common in advanced renal failure, hemoglobin levels were also investigated in respect to plasma calcium levels. As compared to severe or moderate hypercalcemia serum hemoglobin is ele-

Table 2. The level of hypercalcemia in respect to the age distribution of the patients.

\begin{tabular}{|c|c|c|c|c|}
\hline & Mild (10.3-11.9 mg/dL) & Moderate (11.9-14.0 mg/dL) & Severe (Camg/dL) & P value* \\
\hline Patients, n (\%) & 1174 ( 94.37) & $52(4.18)$ & $18(1.45)$ & \\
\hline \multicolumn{5}{|l|}{ Age Groups } \\
\hline 20 years & $148(99.33)$ & $1(0.67)$ & $0(0.00)$ & 0.000 \\
\hline $20-29$ years & 197 (98.99) & $2(1.01)$ & $0(0.00)$ & 0.000 \\
\hline 30-39 years & $152(99.35)$ & $1(0.65)$ & $0(0.00)$ & 0.000 \\
\hline 40-49 years & $155(98.1)$ & $2(1.27)$ & $1(0.63)$ & 0.000 \\
\hline $50-59$ years & $200(92.17)$ & $13(5.99)$ & $4(1.84)$ & 0.000 \\
\hline $60-69$ years & $155(88.57)$ & $13(7.43)$ & $7(4.00)$ & 0.000 \\
\hline 70 years & $167(89.53)$ & $20(10.36)$ & $6(3.11)$ & 0.000 \\
\hline$P$ value & 0.003 & 0.000 & 0.198 & \\
\hline
\end{tabular}

Table 3. Serum calcium levels stratified for the laboratory finding.

\begin{tabular}{|c|c|c|c|c|}
\hline & $\begin{array}{l}\text { Mild hypercalcemia } \\
\text { Mean+SD } \\
\text { Med. (Min.-Max.) }\end{array}$ & $\begin{array}{c}\text { Moderate hypercalcemia } \\
\text { Mean+SD } \\
\text { Med. (Min.-Max.) }\end{array}$ & $\begin{array}{c}\text { Severe hypercalcemia } \\
\text { Mean+SD } \\
\text { Med. (Min.-Max.) }\end{array}$ & $p$ \\
\hline Calcium & $\begin{array}{c}10.84 \pm 0.29 \\
10.75-(10.3-11.94)\end{array}$ & $\begin{array}{c}12.72 \pm 0.59 \\
12.58-(12-13.94)\end{array}$ & $\begin{array}{c}15.65 \pm 1.33 \\
15.32-(14.01-19.35)\end{array}$ & 0.000 \\
\hline Creatinine & $\begin{array}{c}1.09 \pm 1.16 \\
0.86-(0.21-19.04)\end{array}$ & $\begin{array}{c}1.77 \pm 1.79 \\
0.95-(0.52-8.18)\end{array}$ & $\begin{array}{c}2.95 \pm 2.14 \\
2.98-(0.53-9.13)\end{array}$ & 0.000 \\
\hline Urea & $\begin{array}{l}40.02 \pm 28.96 \\
32-(10-276)\end{array}$ & $\begin{array}{c}74.46 \pm 55.71 \\
58.5-(17-264)\end{array}$ & $\begin{array}{l}118.88 \pm 63.42 \\
100-(24-223)\end{array}$ & 0.000 \\
\hline Albumin & $\begin{array}{c}4.82 \pm 0.63 \\
4.9-(0.1-6.8)\end{array}$ & $\begin{array}{l}3.54 \pm 0.86 \\
3.6-(2-5.2)\end{array}$ & $\begin{array}{c}3.29 \pm 0.61 \\
3.5-(2.2-4.1)\end{array}$ & 0.000 \\
\hline WBC & $\begin{array}{c}10.89 \pm 4.28 \\
9.93-(0-38.5)\end{array}$ & $\begin{array}{c}14.53 \pm 8.49 \\
11-(4.23-37.39)\end{array}$ & $\begin{array}{c}19.53 \pm 10.56 \\
15.69-(7.29-42.1)\end{array}$ & 0.000 \\
\hline Hemoglobin & $\begin{array}{l}13.88 \pm 2.19 \\
14-(0-20.9)\end{array}$ & $\begin{array}{c}11.26 \pm 2.61 \\
11.54-(6.63-15.3)\end{array}$ & $\begin{array}{c}10.38 \pm 2.82 \\
10.3-(5.02-14.7)\end{array}$ & 0.000 \\
\hline Trombocyte & $\begin{array}{c}298.44 \pm 110.63 \\
289-(1.52-2166)\end{array}$ & $\begin{array}{l}287.78 \pm 165.69 \\
251-(26.7-744)\end{array}$ & $\begin{array}{c}222.27 \pm 95.6 \\
236.5-(55.09-353)\end{array}$ & 0.005 \\
\hline
\end{tabular}


vated in mild hypercalcemia. Serum albumin level found to be significantly $(p=0.000)$ elevated in mild hypercalcemia compared to moderate or severe hypercalcemia. Also compared to mild hypercalcemia white blood count is elevated in severe hypercalcemia ( $p=0.001$ ). Hemoglobin levels found to be significantly higher in mild hypercalcemia rather than moderate or severe hypercalcemia (Table 3).

Survival among the study samples is significantly $(P=0.002)$ higher in 20 years $20-29$ years of age. Mortality is significantly $(P=0.005)$ higher in70 years

Table 4. Comparison between hypercalcemic patients who survived and those who died.

\begin{tabular}{|c|c|c|c|}
\hline & $\begin{array}{c}\text { Survivors } \\
\text { Mean+SD } \\
\text { Med. (Min.-Max.) }\end{array}$ & $\begin{array}{c}\text { Non-survivors } \\
\text { Mean+SD } \\
\text { Med. (Min.-Max.) }\end{array}$ & $\mathbf{p}$ \\
\hline Calcium & $\begin{array}{c}10.93 \pm 0.8 \\
10.75-(7.92-19.35)\end{array}$ & $\begin{array}{c}12.13 \pm 1.76 \\
11.75-(8.57-15.76)\end{array}$ & 0.001 \\
\hline Creatinine & $\begin{array}{c}1.13 \pm 1.21 \\
0.87-(0.21-19.04)\end{array}$ & $\begin{array}{c}2.92 \pm 2.19 \\
2.28-(0.92-9.13)\end{array}$ & 0.000 \\
\hline Urea & $\begin{array}{c}42.6 \pm 32.39 \\
33-(10-262)\end{array}$ & $\begin{array}{c}110.24 \pm 80.24 \\
93-(24-276)\end{array}$ & 0.000 \\
\hline Albumin & $\begin{array}{c}4.74 \pm 0.71 \\
4.9-(0.1-6.8)\end{array}$ & $\begin{array}{c}3.76 \pm 0.87 \\
3.6-(2.1-5.5)\end{array}$ & 0.000 \\
\hline WBC & $\begin{array}{c}11.18 \pm 4.79 \\
10.06-(0-48.41)\end{array}$ & $\begin{array}{c}18.11 \pm 10.59 \\
13.5-(3.61-42.1)\end{array}$ & 0.001 \\
\hline Hemoglobin & $\begin{array}{c}13.74 \pm 2.29 \\
13.9-(0-20.9)\end{array}$ & $\begin{array}{c}12.41 \pm 2.99 \\
12.94-(6.76-16.5)\end{array}$ & 0.093 \\
\hline Trombocyte & $\begin{array}{c}296.08 \pm 112.14 \\
288-(1.52-2166)\end{array}$ & $\begin{array}{l}269.84 \pm 160.31 \\
283-(51-536.2)\end{array}$ & 0.606 \\
\hline
\end{tabular}

* Mann Whitney U test

Table 5. Comparison between level of hypercalcemia in patients who survived and those who died.

\begin{tabular}{lcc}
\hline & $\begin{array}{c}\text { Survivors } \\
\mathbf{N}(\%)\end{array}$ & $\begin{array}{c}\text { Non survivors } \\
\mathbf{N}(\%)\end{array}$ \\
\hline Mild hypercalcemia & $1160(98.80)$ & $14(1.20)$ \\
Moderate hypercalcemia & $51(98.08)$ & $1(1.92)$ \\
Severe hypercalcemia & $16(88.89)$ & $2(11.11)^{*}$ \\
p & & $0.002^{*}$ \\
\hline
\end{tabular}

${ }^{*} x^{2}$ test

Table 6. Genders of hypercalcemic patients who survived and those who died.

\begin{tabular}{lcc}
\hline & $\begin{array}{c}\text { Survivors } \\
\mathbf{N}(\%)\end{array}$ & $\begin{array}{c}\text { Non survivors } \\
\mathbf{N}(\%)\end{array}$ \\
\hline Female & $625(98.58)$ & $9(1.42)$ \\
Male & $603(98.69)$ & $8(1.31)$ \\
$p$ & 0.530 & 0.808 \\
\hline
\end{tabular}

* $x^{2}$ test of age. The mortality rate increased significantly as the hypercalcemia progressed. Patients with severe hypercalcemia had the highest mortality rate $(11,1 \%$ $\mathrm{p}=0.002$ ) (Table 5). Patients who died had significantly higher calcium, higher white blood count, and lower albumin levels, whereas gender, hemoglobin levels and platelet counts were similar in both survivors and non-survivors (Table 4).

\section{DISCUSSION}

We have presented although hypercalcemia was common electrolyte disturbance in patients in the ED but severe hypercalcemia was rare and fatal. The incidence was much lower in our study than in other studies ${ }^{(4,5)}$. In one of the other studies, the incidence of hypercalcemia was detected $7.5 \%^{(1)}$. Some studies similar to our study, the prevalence of hypercalcemia is low ${ }^{(2)}$. Also the low prevalence of hypercalcemia was detected in hospitalized patients in some studies ${ }^{(12,13)}$.

In our study on more than 120000 ED patients, $0.01 \%$ were identified to have hypercalcemia defined as a serum calcium exceeding $10.3 \mathrm{mg} / \mathrm{dL}$ after correction for serum albumin. Hypercalcemia can be seen in conjunction with other electrolyte should be noted. Especially magnesium and sodium homeostasis should be looked at when evaluating patients ${ }^{(7)}$. The vast majority of our patients had previously been diagnosed with hyperparathyroidism and malignancy. Hyperparathyroidism and malignancy most common cause of hypercalcemia. Similar results have been shown in the etiology of hypercalcemia in many previous studies ${ }^{(4,5,8,9)}$. High incidence of hypercalcemia in patients diagnosed with malignancy is explained by several different mechanisms. These mechanisms depend on type and degree of malignancy. Hypercalcemia is common, especially in cases of advanced cancer or terminal stage. These conditions are considered bad prognosis. The average survival expectancy is usually very short in these patients.

Increased bone resorption, calcium absorption from the intestine and reduction of renal tubular reabsorbion are some of the mechanisms of hypercalcemia in the head. Hypercalcemia is also seen in cases such 
as severe systemic infections, increased cytokine release, diabetic ketoacidosis, liver abscess ${ }^{(1)}$. In some studies, uremia has also shown that hypercalcemia is a common cause. Reduction of renal tubular reabsorbion of calcium, reduced glomerular filtration, hypovolemia, nephrotoxic agents are also effected renal failure. Therefore, hypercalcemia can often occur with acute renal failure due to all these mechanisms. This may explain the high incidence of acute renal failure with hypercalcemia. In other studies, acute renal failure with hypercalcemia is commonly reported ${ }^{(1,10,11)}$.

The clinical range of hypercalcemia is very wide. While not symptoms in the asymptomatic period, symptoms become noticeable as serum calcium levels rise ${ }^{(1,2,14)}$. Depending on the underlying diseases and complications, the increase in serum calcium levels may vary. Therefore, serum calcium levels are very important in patients at risk. Patients with severe hypercalcemia had the highest mortality rate in our study. Patients who died had significantly higher calcium and lower albumin levels, whereas hemoglobin levels, white blood count and platelet counts were similar in both survivors and non-survivors. Similar results to our study have been shown in previous studies ${ }^{(1,2,4)}$.

Our study is limited due to its retrospective. Restrictions such as not documenting all symptoms and symptoms in patients with hypercalcemia, not working with each patient of important data such as Vitamin PTH and Vitamin D, and giving ambulatuar treatment without detecting the underlying disease are in the missing aspects of the study.

Consequently, hypercalcemia is seldom electrolyte disorder in the ED but severe hypercalcemia is rare and harmful. In our study, we found that the mortality rate was higher as hypercalcemia was more severe. Also our results show that in patients with higher hypercalcemia, lower albumin levels, higher age had the highest mortality. Therefore we recommend measuring the serum calcium level in all patients diagnosed with malignancy, both gastrointestinal and neurological symptoms and in at-risk patients in the ED. In at-risk patients, it is important to find the underlying disease starting early in treatment.
Ethics Committee Approval: Bakırköy Dr. Sadi Konuk Training and Research Hospital Clinical Research Ethics Committee approval was received (2020/185).

Conflict of Interest: None.

Funding: No financial support was received.

Informed Consent: Consent was obtained from patients.

\section{REFERENCES}

1. Lee $\mathrm{CT}$, Yang $\mathrm{CC}$, Lam KK, Kung $\mathrm{CT}$, Tsai CJ, Chen HC. Hypercalcemia in the emergency department. Am J Med Sci. 2006;331(3):119-23.

https://doi.org/10.1097/00000441-200603000-00002

2. Lindner G, Felber R, Schwarz C, Marti G, Leichtle AB, Fiedler GM, Zimmermann H, Arampatzis S, Exadaktylos AK. Hypercalcemia in the emergency department: prevalence, etiology, and outcome: Am J Emerg Med. 2013 Apr;31(4):65760

https://doi.org/10.1016/j.ajem.2012.11.010

3. Shek CC, Natkunam A, Tsang V, Cockram CS, Swaminathan R. Incidence, causes and mechanism of hypercalcaemia in a hospital population in Hong Kong. QJ Med. 1990;77(284):127785.

https://doi.org/10.1093/qjmed/77.3.1277

4. Fisken RA, Heath DA, Somers $S$, et al. Hypercalcaemia in hospital patients: clinical and diagnostic aspects. Lancet. 1981;1:202-7.

https://doi.org/10.1016/S0140-6736(81)90071-4

5. Shek CC, Natkunam A, Tsang V, et al. Incidence, causes and mechanism of hypercalcaemia in a hospital population in Hong Kong. Q J Med. 1990;77:1277-85.

https://doi.org/10.1093/qjmed/77.3.1277

6. Bushinsky DA, Monk RD. Electrolyte quintet: calcium. Lancet. 1998;352(9124): 306-11. https://doi.org/10.1016/S0140-6736(97)12331-5

7. Milionis HJ, Rizos E, Liamis G, et al. Acid-base and electrolyte disturbances in patients with hypercalcemia. South Med J. 2002;95:1280-7. https://doi.org/10.1097/00007611-200295110-00011

8. Diamond TH, Botha JR, Vermaak WJ, Kalk WJ. Hypercalcaemia in the Johannesburg Hospital. Differential diagnosis and physician awareness of primary hyperpara- thyroidism. S Afr Med J. 1987;72(2):113-5.

9. Rajathurai A, Cove-Smith R. Hypercalcaemia in Cleveland: a hospital-based survey. J R Soc Med. 1984;77(9):742-6. https://doi.org/10.1177/014107688407700906

10. Levi M, Ellis MA, Berl T. Control of renal hemodynamics and glomerular filtration rate in chronic hypercalcemia: role of prostaglandins, renin-angiotensin system, and calcium. J Clin Invest. 1983;71:1624-32. https://doi.org/10.1172/JCl110918

11. Nash K, Hafeez A, Hou S. Hospital-acquired renal insufficiency. Am J Kidney Dis. 2002;39:930-6. https://doi.org/10.1053/ajkd.2002.32766

12. Dent DM, Miller JL, Klaff L, Barron J. The incidence and causes of hypercalcaemia. Postgrad Med J. 1987;63(743):745-50. https://doi.org/10.1136/pgmj.63.743.745

13. McLellan G, Baird CW, Melick R. Hypercalcaemia in an Australian hospital adult population. Med J Aust. 1968;2(8):354-6

https://doi.org/10.5694/j.1326-5377.1968.tb82823.x

14. Ziegler R. Hypercalcemic crisis. J Am Soc Nephrol. 2001;12(Suppl):S3-9. 